Int. J. Morphol.,

35(2):547-551, 2017

\title{
Diaphanization: A Standardized Protocol for Non-Fetal Tissue Preservation
}

\author{
Diafanización: Un Protocolo Estandarizado para la Preservación de Tejido Adulto
}

\author{
Roberto Javier Rueda-Esteban'; Juliana Palacio Varona²; \\ Juan Sebastián López-McCormick² \& Juan David Hernández Restrepo ${ }^{3}$
}

RUEDA-ESTEBAN, R. J.; PALACIO, J. V.; LÓPEZ-MCCORMICK, J. \& HERNÁNDEZ, J. D. R. Diaphanization: a standardized protocol for non-fetal tissue preservation. Int. J. Morphol., 35(2):547-551, 2017.

SUMMARY: In response to the arising difficulty of dissection use during anatomy courses, medical schools have been forced to research alternative teaching methods. These are meant to help students develop three dimensional mental images of the human body and increase spatial reasoning, thus improving the learning process of human morphology. One of those methods, used at the Universidad de los Andes is the Diaphanization process. This technique is a well-known method for specimen preservation, used as an anatomy research and teaching tool. Even though it is frequently used, finding a standardized protocol in indexed journals is not possible, which hinders the use of the technique. The standardization of an updated protocol is a need in order to continue exploiting the maximum educational capacity of the specimens used during classwork. The process used at the Universidad de los Andes for non-fetal tissue preservation by Diaphanization is described, with a detailed explanation of its five main stages: Injection, Fixation, Dehydration, Bleaching (or Maceration) and Final preservation. The final result should be an organ preserved in an acrylic box which allows clear three dimensional visualization of anatomical structures that can be used for the study and description of general anatomy and vascular structure. It also helps with spatial reasoning and represents little to no biological risk, leading to a new level of anatomical teaching and experimenting. Several specimens obtained at our laboratory through this technique are presented.

KEY WORDS: Teaching of anatomy; Diaphanization; Preservation of Adult Tissue; Standardized protocol.

\section{INTRODUCTION}

Anatomy is one of the pillar disciplines in medical studies, and dissection became the main teaching tool since 1800’s (Korf et al., 2008). Modern educational programs that include dissection in their curriculum are based on donor programs, which make Anatomy courses costly and labor intensive (Rizzolo \& Stewart, 2006). Currently, the difficulty to obtain human bodies for educational purposes is increasing, (Aversi-Ferreira et al., 2010) forcing medical schools to search for alternative methods to complement dissection. Such methods have had various forms, as computer programs, websites and the use of diagnostic images (Korf et al.). The main problem with these technologies lies in the inability to generate functional three dimensional images, which in turn means students cannot develop a three dimensional mental image of the human body, compromising spatial reasoning (Rizzolo \& Stewart). Taking this into account, medical schools have invested in a variety of preservation techniques which have the advantages of prolonging the shelf life of specimens, reducing cost, generating a three dimensional image and preserving unique or pathological specimens (Riederer, 2014).

From the pedagogical point of view, practical activities such as producing specimens, are more effective as a learning process than just memorization (Aversi-Ferreira et al.). With the increased durability of the specimens, students are able to interact with real life models of what is described in their Anatomy textbooks, resulting in a better understanding of studied structures.

After educational psychology was founded in 1906, the information processing theory for learning has been used to enhance the process of teaching. This theory divides the memory in three components: sensory memory, working

\footnotetext{
${ }^{1}$ Anatomy for Education Research Group, Universidad de los Andes, School of Medicine Assistant Professor, Anatomy Laboratory Coordinator.Bogotá D.C. Colombia. ${ }^{2}$ Anatomy for Education Research Group, Universidad de los Andes, School of Medicine Student, Bogotá D.C. Colombia.

${ }^{3}$ Anatomy for Education Research Group, Universidad de los Andes School of Medicine, Anatomy and Surgery Clinical Professor. Bogotá D.C. Colombia.
} 
memory and long-term memory (Terrell, 2006). According to it, making or using specimens may enhance sensory memory to incorporate new information from visual and sensory stimuli. The working memory (short-term memory) is also used, beginning with the awareness of new knowledge generated by the process of preserving a specimen and the comparison of the anatomy of the specimen to the class textbook. All of these factors help the student to filter new information selectively and generate a cognitive output (Terrell). Based on this theory, the importance of using preservation techniques in the Anatomy Laboratory and course is noticeable. This paper will describe the diaphanization technique of adult specimens.

Diaphanization was first described by Spalteholz in 1911 (Steinke \& Wolff, 2001). The main physical principle for the technique is to equalize the refraction indexes of the organ or specimen and the medium in which it is embedded, leading to bleaching of the organ which allows the observation of its internal structure allowing clear three-dimensional visualization of anatomical structures (Steinke \& Wolff). This is accomplished by replacing the interstitial fluid of the specimen with a fluid which has a similar refractive capacity to the specimens (Tilotta et al., 2009). Ink, latex, or polymers can be used to highlight structures that can be injected or colored while producing no changes in the surrounding tissue.

This method is mainly used in research, but is also used in the development of teaching specimens for Anatomy. It has been employed to describe and demonstrate vascular and nervous anatomy in different embryologic developmental stages. Example of that is the study of bone development centers forming in elbow joints (Visco, et al., 1990). Some of the examples that exist in adults' research are: the study of morphology of nerves and blood supply in rats (Ang, et al., 2013), the venous anatomy of the scaphoid in humans (Handley \& Pooley, 1991) and intraosseous vascularity of the distal radius (Lamas et al., 2009).

Summarizing, this technique is a well-known method for the preservation of specimens, but the majority of available literature describes it briefly and as a part of a research paper, therefore, the technique itself is not well explained and a protocol of how it should be done is not readily available.

\section{MATERIAL AND METHOD}

Injection: Usually when a non-fetal specimen is prepared, the vascular, respiratory or other tubular structures are highlighted. To achieve this, injection of a colored polymer or ink should be performed to the organ in fresh, before fixation. This can be accomplished with the introduction of a tube or catheter in the vessel, which is tied to avoid spillage. A syringe containing the polymer or ink is used to fill the lumen of the structure as required, following the Injection (Repletion) protocol of each institution.

Diaphanization: For adult tissue, the process can be divided into four main steps: Fixation, Dehydration, Bleaching, and Final preservation.

Specimens are fixated with a solution of $4 \%$ formaldehyde. Any dissection desired on the specimen should be done prior to this step. Suggested time for fixation is 7 days, allowing the complete cleavage of proteins.

The dehydration process enhances maceration effectivity by $\mathrm{KOH}$, increasing the fixation and eliminating undesired water from the specimen. During this step the calcified tissue can be stained. The dehydration process consists on a series of immersions with Ethyl alcohol or Isopropyl alcohol going from a 70 $\%$ dilution to absolute, increasing $10 \%$ in each solution. Each step should last four days to achieve complete gradual dehydration, to avoid damage. Inappropriate gradual dehydration could result in tissue retraction which would alter shape and defeat the purpose of the technique decreasing the didactic value of the specimen. However, specimens that have been kept in alcohol for long periods of time (even years) can be macerated too. In our experience, the time of dehydration, even if excessive, does not affect maceration. In any case, rapid immersion in highly concentrated solutions can damage the sample as explained before.

Bleaching or macerating of the specimen is the most delicate step of this process due to the corrosive substances used. It is accomplished by the immersion in solutions of potassium hydroxide $(\mathrm{KOH})$ which produces an irreversible hydrolysis of the organ. $\mathrm{KOH}$, as a strong base can cause extreme damage if the concentration and timing are not carefully controlled. These variables depend on the size of the organ and type of tissue. We recommend beginning with concentrations of $4 \%$ (weight/volume of $\mathrm{KOH} /$ water) in specimens around 50 $\mathrm{cc}$ in volume. If it is smaller, the starting concentration should be $2 \%$. For any specimen, if maceration does not occur, concentration can be increased gradually by $2 \%$ but never exceeding a final concentration of $15 \%$, since higher concentrations may lead to definitive hydrolysis and damage of the specimen. In case of larger specimens, with more than $200 \mathrm{cc}$ of volume, the initial concentration can be $8 \%$ (Table I). 
Table I. Correlation between the volume of the specimen and suggested initial $\mathrm{KOH}$ concentration to be used in the hydrolysis process.

\begin{tabular}{lcl}
\hline Volume (cc) & Concentration (\%) & \multicolumn{1}{c}{ Special Considerations } \\
\hline$<50$ & 2 & Initial concentration for small specimens. \\
50 & 4 & $\begin{array}{l}\text { Recommended starting concentration for most specimens. } \\
\text { Recommended starting concentration for big specimens. More than } 15 \% \text { will lead to } \\
\text { definitive hydrolysis, and subsequent tissue damage }\end{array}$ \\
\hline
\end{tabular}

If damage or partial destruction of the organ is detected, the specimen must be submerged in a solution at the previous concentration, never decreasing the concentration more than $50 \%$. This should stop the process of hydrolysis. The process ends when the amount of bleaching desired is achieved, usually when the specimen turns to a white/semi-transparent tone, as it will continue to diaphanize in the next step.

In order to achieve transparency or translucency, the organ should be embedded in anhydrous glycerin, changing it regularly, until glycerin stops becoming dark and producing a supernatant. The specimen now can be sealed either in acrylic boxes submerged in anhydrous glycerin, which will give it structural support, or in some other form of packaging, but always submerged in glycerin. As the specimen becomes tremendously fragile it is recommended to submerge the specimen in glycerin in the final container in which it will be stored, attaching it to the box or making it as tight as possible.

If the transparency or translucency is lost with the pass of time, the organ can be placed again in solutions of

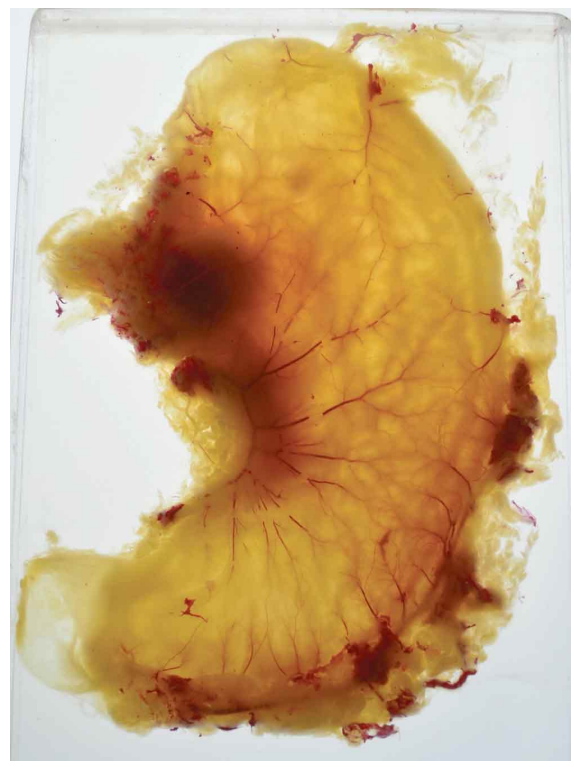

Fig. 1. Partially Diaphanized human stomach anterior view, selectively injected with methylmethacrylate for contrast.
$\mathrm{KOH}$ at $1 \%$ or $2 \%$ until the transparency desired is reached again, after which the packaging process should be repeated.

\section{RESULTS}

Using the technique described the laboratory of Anatomy of the Universidad de los Andes School of Medicine, has produced a variety of specimens, including hearts, stomachs, spleens, and livers, both human and animal in origin. All specimens were previously injected with selfcuring acrylic (methyl-methacrylate).

The final result is an organ preserved in an acrylic box which allows the clear three dimensional image of anatomical structures that can be used for the study and description of general and vascular anatomy (Fig. 1).

The time the specimen remains in the $\mathrm{KOH}$ solution determines its transparency, as can be seen in Figures. 2, 3 and 4 . The specimen in Figure 3 was left for a shorter time period than the one in Figure 2, resulting in an incomplete or partial diaphanization.

Unusual anatomical specimens can be studied with this technique. An example of this are horseshoe kidneys, where the irrigation can be better observed, as shown in Fig. 5.

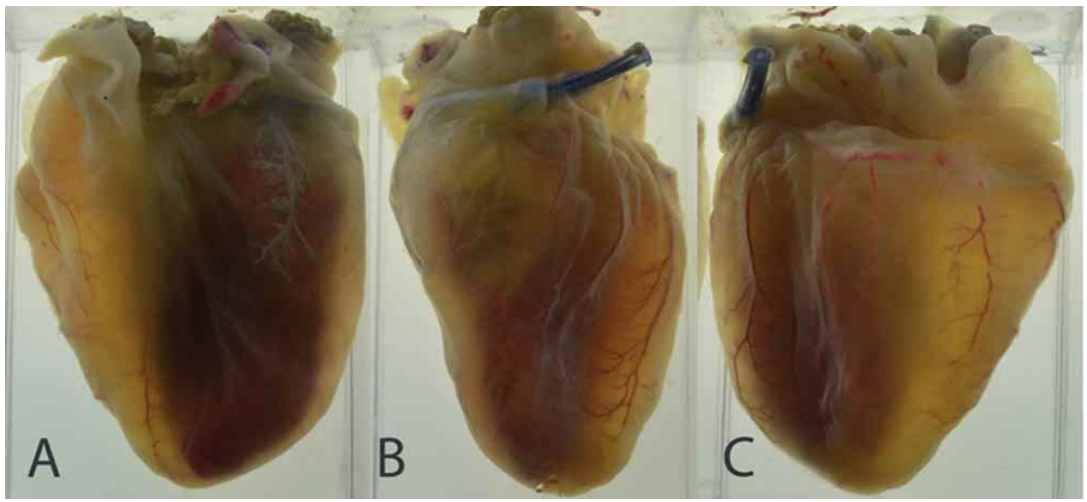

Fig. 2. Fully Diaphanized porcine heart, selectively injected with methyl-methacrylate for contrast. A. Ventral view. B. Lateral view. C. Dorsal view. 


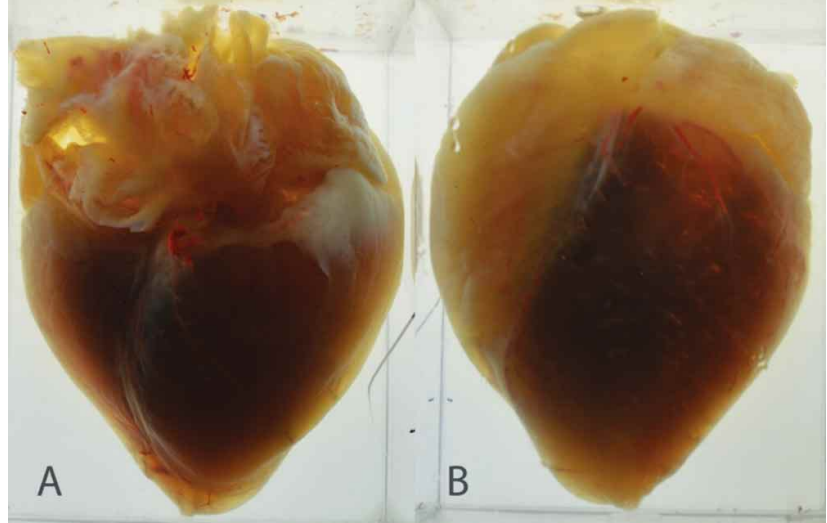

Fig. 3. Partially (Deep) Diaphanized porcine heart, selectively injected with methyl-methacrylate for contrast. A. (Left) Dorsal view. B. (Right) Ventral view.

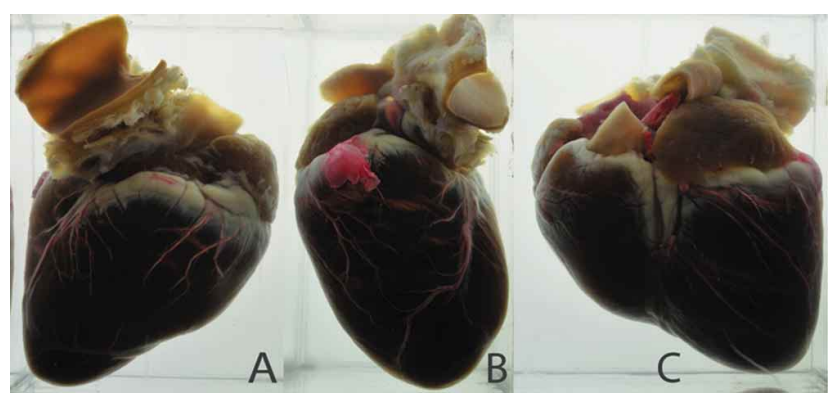

Fig. 4. Partially (superficial) Diaphanized human heart, selectively injected with methyl-methacrylate for contrast. A. (Left) Anterior view. B. (Middle) Lateral view. C. (Right) Posterior view.

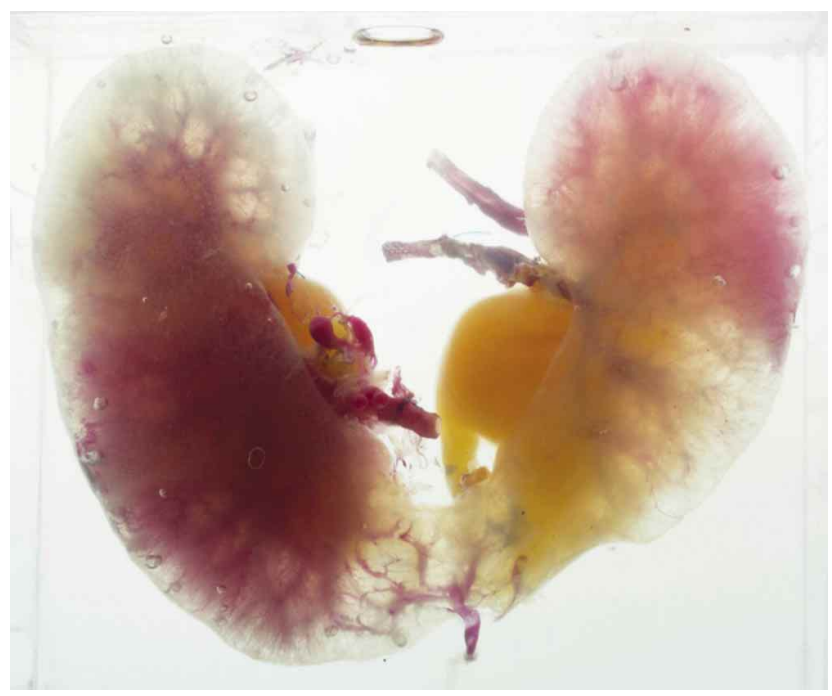

Fig. 5. Fully Diaphanized Horseshoe Kidneys. Shared irrigation can be observed in the inferior renal pole. Arteries selectively canalized and injected with Methyl-Methacrylate.

\section{DISCUSSION}

Traditionally, students have used cadavers for dissection, individuals that are buried and not usually preserved more than one term. While beneficial for that group of students, any interesting findings are lost for the rest of the community. Using alternative methods of preservation, organs and specimens can be used by several generations of students.

Diaphanization permits the preservation of specimens with very high academic and didactic value, thanks to the three dimensional image of anatomical structures and the visualization of internal structures without altering its original organization. It gives students the ability to develop a three dimensional mental image of the human body, thus increasing spatial reasoning. The results of Diaphanization are very fragile specimens that can be kept in acrylic boxes with glycerin to prevent any damage of the tissue caused by manipulation by students. However, once preserved with this method, the specimens can last years and be very resilient even in the hands of inexperienced students, provided they are kept in an appropriate container.

The organs preserved by Diaphanization at the Universidad de los Andes have been used in the Anatomy course as valuable tools for teaching, not only as real models in class, increasing the number of models available for classwork and the museum, and actively engaging the students in their production.

Thanks to the long shelf life of the specimens they can be used for many generations of students. Storage in acrylic boxes reduces biohazard issues and damage.

The use of the specimens in class can generate positive results in knowledge gained by the students. It decreases the dissection time and minimizes the damage done to classical formolized specimens due to the lack of experience in students. It also helps create spatial relations and reasoning.

\section{ACKNOWLEDGEMENTS}

To the students of the Group for research in Anatomy and Education of the Universidad de los Andes, for their help in the development of these specimens and the Universidad de los Andes Faculty of Medicine for funding this research. 
RUEDA-ESTEBAN, R. J.; PALACIO, J. V.; LÓPEZ-MCCORMICK, J. \& HERNÁNDEZ, J. D. R. Diafanización: Un protocolo estandarizado para la preservación de tejido adulto. Int. J. Morphol., 35(2):542-547, 2017.

RESUMEN: Como respuesta a la dificultad del uso de disección como una herramienta en el curso de anatomía, las escuelas de medicina se han visto forzadas a investigar y desarrollar métodos alternativos que la reemplacen. Estos pretenden estimular el desarrollo de la percepción tridimensional de los estudiantes, logrando mejor racionamiento espacial, y así, mejorando el proceso de aprendizaje de la morfología humana. Uno de estos métodos, en uso en la Universidad de los Andes, es el proceso de diafanización. Esta técnica es ampliamente conocida en el ámbito de preservación de tejidos, y empleada en investigación y educación. Aún con su uso frecuente, un protocolo estandarizado que la describa no está disponible en la literatura indexada, lo cual limita su uso. La estandarización de un protocolo actualizado es necesaria para permitir el continuo uso de esta técnica. Se describe el proceso de preservación de tejido adulto mediante la diafanización, con una explicación detallada de los 5 pasos que la componen: Inyección, Fijación, Deshidratación, Macerado y Preservación final. El resultado es un órgano inmerso en glicerina en un contenedor de acrílico que permite una visualización tridimensional de las estructuras anatómicas del espécimen, que puede ser empleado por los estudiantes para su estudio, y permite una descripción de la anatomía general del modelo y su estructura vascular. Adicionalmente incrementa el razonamiento espacial de los estudiantes, y no presenta ningún riesgo biológico. Se presentan una variedad de especímenes de características particulares obtenidos mediante la aplicación de esta técnica.

PALABRAS CLAVE: Enseñanza en Anatomia; Diafanización; Preservación de tejido adulto; Protocolo Estandarizado.

\section{REFERENCES}

Aversi-Ferreira, T. A.; Nascimento, G. N. L.; Vera, I. \& Lucchese, R. The practice of dissection as teaching methodology in anatomy applied to medical education. Int. J. Morphol., 28(1):265-72, 2010.

Handley, R. C. \& Pooley, J. The venous anatomy of the scaphoid. J. Anat., 178:115-8, 1991

Korf, H. W.; Wicht, H.; Snipes, R. L.; Timmermans, J. P.; Paulsen, F.; Rune, G. \& Baumgart-Vogt, E. The dissection course - necessary and indispensable for teaching anatomy to medical students. Ann. Anat., 190(1):16-22, 2008.

Lamas, C.; Llusà, M.; Méndez, A.; Proubasta, I.; Carrera, A. \& Forcada, P. Intraosseous vascularity of the distal radius: anatomy and clinical implications in distal radius fractures. Hand (N. Y.), 4(4):418-23, 2009.

Riederer, B. M. Plastination and its importance in teaching anatomy. Critical points for long-term preservation of human tissue. J. Anat., 224(3):309$15,2014$.

Rizzolo, L. J. \& Stewart, W. B. Should we continue teaching anatomy by dissection when ...? Anat. Rec. B New Anat., 289(6):215-8, 2006.

Steinke, H. \& Wolff, W. A modified Spalteholz technique with preservation of the histology. Ann. Anat., 183(1):91-5, 2001.

Terrell, M. Anatomy of learning: instructional design principles for the anatomical sciences. Anat. Rec. B New Anat., 289(6):252-60, 2006.

Tilotta, F.; Lazaroo, B.; Laujac, M. H. \& Gaudy, J. F. A study of the vascularization of the auricle by dissection and diaphanization. Surg. Radiol. Anat., 31(4):259-65, 2009.

Visco, D. M.; Hill, M. A.; Van Sickle, D. C. \& Kincaid, S. A. The development of centres of ossification of bones forming elbow joints in young swine. J. Anat., 171:25-39, 1990.

\author{
Corresponding author: \\ Roberto Javier Rueda Esteban \\ Laboratorio Anatomía \\ Carrera 1 No. 18a -10, Sótano Y006 \\ Bogotá \\ COLOMBIA
}

E-mail: rj.rueda32@uniandes.edu.co

Received: 25-08-2016

Accepted: 16-03-2017 